\title{
The struggle for individuality: Investigating a long-term pursuit of a lifestyle sport activity
}

\author{
Jana Hoffmannovái ${ }^{1, *}$, Luděk Šebek ${ }^{1}$, Pete Allison² ${ }^{2}$, Michael Maina ${ }^{3}$, and James Toogood ${ }^{2}$ \\ ${ }^{1}$ Faculty of Physical Culture, Palacký University Olomouc, Olomouc, Czech Republic; ${ }^{2}$ Moray House School of Education, \\ The University of Edinburgh, Edinburgh, United Kingdom; and ${ }^{3}$ Roanoke College, Salem, VA, United States
}

Copyright: (C) 2016 J. Hoffmannová et al. This is an open access article licensed under the Creative Commons Attribution License (http://creativecommons.org/licenses/by/4.0/).

\begin{abstract}
Background: Mainstream forms of media frequently portray "wild" or "epic" images of lifestyle sport activities showing the participants as "modern-day gladiators". This research set out to explore how closely aligned these stereotypes are with individual experiences. Objective: The purpose of this study was to identify and analyze factors which may contribute to a selected lifestyle sport activity becoming firmly rooted in an individual's life course. Methods: Data were collected through focus groups, individual interviews, lifeline method, and participant observation within focus groups. The sample included performance freeskiers, freestyle snowboard riders and instructors $(N=19)$. Grounded theory was used for analysis and interpretation of data. Results: Results from this research indicate traditional deterministic images of a sport career in freeskiing and freestyle snowboarding do not match the views and beliefs of the actual participants in these activities. Conclusions: The study examines the careers of long-term participants in freeskiing and freestyle snowboarding and extends existing knowledge of lifestyle sports through the implementation of the lifespan approach. Recommendations for future research include extending the analysis to include sports recently considered mainstream as the distinction (between mainstream and lifestyle sports) is becoming increasingly complicated.
\end{abstract}

Keywords: freeskiing, freestyle snowboarding, lifespan psychology, leisure, sport career

\section{Introduction}

Throughout history humans have experienced the need for both intrinsic and extrinsic forms of motivation ranging from survival purposes to personal enjoyment in activity (Deci \& Ryan, 2008). Johnson, Bolter, and Stoll (2014) build on the work of Ryan and Deci (2000) in self-determination theory, which suggests humans have three fundamental psychological needs that, if satisfied, are indicators of health and well-being. These needs are competence, autonomy, and relatedness. The following article builds on the premise that participation in lifestyle sport activities can provide opportunities for the satisfaction of these needs. Satisfaction, as such, cannot be separated from other, sometimes competing interests (Wheaton \& Beal, 2003). Levels of satisfaction may range from commercial to

\footnotetext{
* Address for correspondence: Jana Hoffmannová, Department of Recreology, Faculty of Physical Culture, Palacký University Olomouc, třída Míru 117, 77111 Olomouc, Czech Republic. E-mail: jana.hoffmannova@upol.cz
}

societal. Commercialization and commodification of the images of risk, adrenaline, and adventure, for example (Rinehart \& Sydnor, 2003; Šebek, 2011) is broadly discussed and their impact on the development of lifestyle sports role should be understood as rather complex (Donnelly, 2006; Wheaton, 2004).

On the one hand, the interviewed long-term participants observe the freedom, creativity, and "coolness" of lifestyle sports are largely "lost in translation" due to the commercialization by various forms of marketing agencies. On the other hand, these agencies along with a variety of media outlets often encourage and inspire lifestyle sport participants to explore new horizons which in turn results in new forms of invention of innovative variations. The multi-faceted relationship between lifestyle sport subcultures valuing their uniqueness in self-expression and commercial subjects seeking to turn these values into commodities is rather pronounced in the cases of freestyle snowboarding and freeskiing (Wheaton \& Beal, 2003). Breivik (2010) builds on this concept when he refers to adventure sports and believes that they are arenas where modern 
risky life projects can be staged in a clear and comprehensible way. Based on previous scholarly work, a lifespan view appears essential for deeper understanding of the underlying factors concerning long-term participation in lifestyle sports (Brymer \& Oades, 2009; Celsi, Rose, \& Leigh, 1993; Csikszentmihalyi, 2009; Le Breton, 2000; Loland, 2007).

This article investigates the life course of lifestyle sports athletes using a lifespan psychology that focuses on development throughout a person's lifetime, "from womb to tomb" as discussed by Stambulova, Alfermann, Statler, and Côté (2009).

The research focuses on understanding the factors that contribute to a long-term sustainable sport career for high performance lifestyle sports participants. For the purpose of this study the term "high performance" will refer to individuals who are able to compete or professionally perform at a superior level in their sport. The design of this study was built upon the assumption that all phenomena (biological, psychological, social, and environmental) are interdependent (Hoffmannová, 2011). Instead of treating events within individual life stages as static and isolated it recognizes the existence of many overlaps in human lifespan. Becoming a top performing freeskier or freestyle snowboarder is a social-historical process, which can usefully be interpreted in relation to the individual's personal history (Wylleman, Alfermann, \& Lavallee, 2004). In the athlete's life we can observe milestones and transitions that define the direction of their further development (Alfermann \& Stambulova, 2007). Stuart and Smith (2014) refer to Denzin (1989) and Leonard and Burns (2006) suggesting that critical incidents and events can be the catalyst for epiphanies and turning points which (consequently) have the capacity to change life trajectories. The resulting life transitions may be positive when the events offer new exciting chances as well as negative when opportunities are severely denied. Denzin (2014) emphasizes the role of the epiphanies and the personal-experience as well as self-stories that represent and shape an individual's life. The lifespan perspective and recognition of the formative impact of individual life events is growing in importance in kinanthropological research in the Czech Republic (Hoffmannová, 2011; Hrouda, 2004; Valenta, 2009; Válková, 1990). Recent developments in sports psychology are marked by the demand for a broader range of analyses of the influence of social, cultural, and historical contexts on the individual's sport behavior (Thorpe, 2009). Understanding of the cultural context is particularly important in attempts to explain the experience of athletes involved in such lifestyle sports as freeskiing and freestyle snowboarding (Thorpe, 2011; Wheaton, 2004, 2013). The following study seeks to portray the metaphor of journey in the interviewees' reflections throughout their sport career. As a result this study will focus on the interrelations of past events, present experience, and anticipated future actions during the careers of the studied lifestyle sports athletes.

\section{Methods}

\section{Participants}

The research sample was composed of 12 male and 7 female riders $(N=19)$ between the ages of 17 and 33 years who compete or teach in the fields of freeskiing and freestyle snowboarding; the average age was 23.5 years. The participants were Czech of primarily middle to higher socioeconomic status. Within these groups there were nine freestyle snowboarders, eight freeskiers, and two instructors (freeskiing and freestyle snowboarding) with an average of 7.1 years' experience (ranging from 4 to 16 years). The sample was accessed through gatekeepers (Maxwell, 2005) familiar with the researched community and respected for their individual sport achievements by other members of the community. Participants knew each other. Purposive sampling was used with the criteria of competing or instructing in freeskiing or freestyle snowboarding. Informed consent was obtained for all subjects participating in this study. The study design was approved by the Ethics Committee of the Faculty of Physical Culture, Palacký University Olomouc.

\section{Procedures}

Qualitative data were primarily collected through the lifeline method which focuses on subjective perception of significant events in the life course of the studied athletes, and their possible links to participation in lifestyle sports, which forms the central focus of the study (Assink \& Schroots, 2010; Miovský, 2006). Focus groups and individual interviews unfolded from the participants' lifeline drawings. Focus groups are particularly useful when studying tribal-type lifestyle sports communities (Thorpe, 2012) where group reflections are a natural part of the shared experience. The focus group method was used to provide an "organic" format for lifestyle sport participants in this study (Morgan, 1997; Šebek \& Hoffmannová, 2010). In addition, the researchers also employed the use of participant observation in order to reflect the social dimension of the focus group interviews.

Focus group sessions averaged approximately 80 minutes in length and yielded a total of 320 minutes of voice-recorded data. All group recordings were subsequently transcribed and coded using the 
qualitative analysis software ATLAS.ti (Version 7; Scientific Software Development GmbH, Berlin, Germany). Individual interviews sessions averaged approximately 50 minutes in length for a total of 160 minutes of voice recorded data, which was also transcribed and coded using ATLAS.ti software. The interview data including the interpretations of the lifeline diagrams were analyzed within the framework of grounded theory (Bryant \& Charmaz, 2007; Charmaz, 2003; Edwards \& Skinner, 2009; Strauss \& Corbin, 1990). Open coding was followed by complete re-coding leading to the first reduction of the code base and creation of concepts. Common themes relating to the long term pursuit of lifestyle sport emerged from selective coding and identification of conceptual relations. As most significant concepts in terms of density and groundedness surfaced individuality, fellowship, external conditions, and environmental factors that had affected the participants' life direction. Three main categories - discussed past events, recent experience, and anticipated future events - were analyzed in relation to the main category, which was the long-term presence of a lifestyle sport activity in the interviewees' life journey. Sorting memos and comments on conceptual links revealed more general relations to three themes: 1) the dynamic view on the human life course relates to the formative role of critical life incidents and epiphanies and their interpretation contrasting with idealized images of sport career trajectories; 2) individualization as creative processes embodies the sum of ideas referring to the constructive aspect of a largely self-managed leisure career; 3 ) the metaphor of a journey weaves the first two themes together.

\section{Results and discussion}

For the purposes of logic and clarity, results and discussion of data analysis together will be provided within three distinct sections reflecting the themes from the previous paragraph.

\section{Dynamic view on the human life-course}

In addition to the variety of themes researched in the field of lifestyle sports (e.g. Rinehart, 2008; Rinehart \& Sydnor, 2003; Thorpe, 2012; Wheaton, 2004, 2013) the primary focus of this study was devoted particularly to the dynamics of career and life course, in response to Stebbins' (2004, p. 20) "bringing out the fluidity of leisure and its plastic intersection of other aspects of life". Our study illustrates the unpredictability of leisure careers in the 21st century. For Mia, an Olympic skier (24) a sport injury represented a critical life event leading to epiphany which was a catalyst for a major transition in her leisure career:

I had done gymnastics for what now feels like a thousand years before I got injured and my world collapsed. Then I figured that the ankle wouldn't matter so much when fixed inside a ski boot and started performing with aerials and soon did pretty well. At that time I had little clue what freeskiing was. The guys (freeskiers) kept inviting me to join and jump with them. I'd always refuse saying I had no time and that I had my training and so on until I dared to put something simple together a day before a local contest. It wasn't much at all but from there I just sort of went on jumping throughout the summer - the more I learnt the more stoked I was.

The observed unpredictability of leisure careers contrasts with the images of ceaseless expansion of stock of various forms of capital (e.g. material wealth, physical health, emotional resilience, or professional expertise) common in the rhetoric of institutionalized sport. Stuart and Smith (2014) argue that the careers' idealized trajectory can be undermined by critical incidents that strip the athletes of their stock of capital as well as offer opportunities to re-claim it. Beyond highlighting the contrast, data indicate that what matters to the athletes is whether they feel that their talents can flourish or fade through taking part in the activity. In their words they speak about feeling or not feeling "like themselves". Jakub, a snowboarder, stated: "It all clicked together and I felt it was me out there on the mountain again" (Jakub, 21, snowboarder, focus group 1). Similarly, Jana (26, professional freeskier, focus group 2) relates to her experience of riding in moguls stating:

I was winning medals and I did keep getting better, but then I just couldn't find myself in it. That whole little world was getting too tight and I found it hard to breathe. Then I moved on to freeskiing and it was like being born back to my original body again.

Movement through life is not only constrained by socialized experiences of childhood and adolescence, but also enabled by the capacity to respond to transition points in adulthood. The past turning points affect the athletes' interpretations of their experienced present. Significant present experiences on the rebound often require the athletes to reconsider the impacts of past transitions in new perspective. These dynamics shape the athlete's images of their anticipated future.

\section{Individualization as a creative process}

Stebbins (2005) believes that deep and satisfactory involvement in leisure pursuits is typically based on 
the presence of some combination of skill, knowledge, and talent. He connects the desires to realize talents and develop oneself with finding personal fulfillment. The term "individualization" similarly refers to the process of realizing, understanding, and addressing what Robinson and Aronica (2013) refer to as the personal "element".

Athletes reported "being a coach to oneself", and feeling of co-ownership through "imprinting one's individual style in the activity". Viewing their anticipated future, the respondents look for possibilities to retain the independence and freedom aspects of their recent sport activity, ideally remaining in the fields of snowboarding or freeskiing. Some plan to shift towards the creative dimension of the sport, making or producing videos or photography, others plan to coach young riders, and some would like to establish their own brand of equipment, etc.

This is not the same as the way the term individualization is used in sport training where it is often understood as a process driven at large externally (Silva, Metzler, \& Lerner, 2007). In that context, the term relates to an "individual approach" outlined by the idea of designing and modifying training strategies according to the individual needs of the athlete. Instead, for the purposes of this article, individualization is defined as a creative process involving the reflective self. Lehnert, Hoffmannová, Neuls, Botek, and Šebek (2012) see the lifespan approach as connecting the instrumental approach to individualization of sport training with a humanistic approach. The instrumental approach understands individualization as a collection of methods, strategies and procedures. The rationale behind it is that a personalized training process can be more effective. While the individual training needs of the athletes are given consideration, the responsibility for their diagnostics lies predominantly within the coach. From the point of view of long term adherence to the sport activity "there can be lack of creative investment, interest and responsibility on the part of the athlete" (Lehnert et al., 2012, p. 137). The humanistic approach puts the coach into the role of a facilitator. It allows the athlete to participate in the planning and decision making about the execution of the training as well as evaluation of the results. Lifespan approach puts the coach in the partnership role of a guide, the fundamental principle being the endeavor to sustain long term development throughout and even beyond the sport career (Alfermann \& Stambulova, 2007; Wylleman et al., 2004). For example Robert, a freeskiing instructor states:

For me it represents a space for some kind of selfexpression. I can do things I enjoy and do them the way I want and not that someone tells me what and how I should do. It's my choice where and what I jump, where I ride and where I don't. The people around who have similar opinions are important, too. I can guide young riders, you know. It's about being there with them when they work their own way towards independence. (Robert, 28, freeskiing instructor, focus group 3)

As a coach, this individual reflects an internalist conception where responsibility is largely shared between the athlete and the coach where the coach is perceived as a companion to the athlete. This allows less hierarchical social arrangement. In the interviews, autonomy, relatedness, and competence are woven into a tapestry of a "tribal" play (Atkinson \& Young, 2008) community. The communities of freestyle snowboarders and freeskiers are considered as the foundational basis or the soil potentially enabling their participants' talents to flourish. The athletes' repeatedly stressed shared recognition of nurturing a talent being inseparable from the lifelong journey of self-discovery suggests a thread of intrinsic motivation. This has been recently suggested to be key for individuals to sustain an active lifestyle (Yli-Piipari, Wang, Jaakkola, \& Liukkonen, 2012). At the same time the athletes' reflections reveal notions of an ongoing internal as well as external negotiation. For the lifestyle sport participants, deep and long-term immersion is inevitably confronted with the activity's transformation, e.g. due to commercialization and commodification. It is also inevitable that the athletes contribute to this change through negotiating a compromise between having a share of the economic benefits of sport commerce and preserving the "alternative" culture of lifestyle sport activities.

\section{Metaphor of journey}

The journey of each individual athlete is naturally of significance in the interpretation of a lifeline-based study. Through self-education, the formative process is turned into a longitudinal act of self-creation, which culminates, hopefully, in self-actualization. Hodan̆ (2009, p. 127) contemplates that: "Looking for the meaning is thus always connected with activity, with walking the path to the set goal - life is an open journey. " Accordingly, the term "meaning" plays a route-identification role in human life. Young and Atkinson (2008) relates self-determination to choosing or devising a plan for life, rather than having one imposed by others, and actively shaping his or her life so as to realize choices and decisions. Vincent, a freestyle snowboarder states:

The basic difference is that this is the first sport where I, in fact, have fun even when I actually fail. If it is meant to be done on long-term basis, you need to enjoy the learning part, not just the result. 
(Vincent, 29, professional freestyle snowboarder, focus group 2)

Šebek (2011) illustrates the dynamics of form and growth in a lifestyle sport career. Form is related to the lifestyle sport "mantra" of originality. Since succeeding as a professional snowboarder or freeskier requires certain snappiness and marketing skill, this component often plays an important role in the athlete's career. On the other hand, domination of this aspect is typically characterized by intrinsic insubstantiality. The journey of "layer by layer" growth from within can be described as progressive construction of personal and social structure. Adam, a pioneer of freeskiing in the Czech Republic, states:

One got to a certain competition level but it was a sport with clear chalk lines and basically you had to always ride the same thing and felt no freedom. I was always attracted to the freedom aspect of freeskiing so I took that path where you were on your own, for yourself, as a supplement to the moguls. Now it's kind of funny there were just five of us at the beginning. And today there are - I don't know - three thousand in the sport? And most seem to feel obliged to be original but many are original the same way. (Adam, 26, focus group 2)

Extrinsic pressures like the obligation to meet the standard of originality may include those imposed by sport business and media (Wheaton, 2004). Corresponding with Rinehart's (2008) findings regarding the counterculture and resistance ethos of lifestyle sports, our participants' refer to an ongoing negotiation of free play and authenticity with various commercial interests outside and within the community. Emil, 20, professional snowboarder from focus group 2 contemplates:

So one needs to think a bit about other things and take the sport as a sort of fun because if one sacrifices everything to it and then gets hurt, or some find out that they can't keep up with the progress and have no school and nothing, then they quit and are screwed up. One should begin the sport with having in mind that the fun part should outweigh the other rather than going like "I'm gonna make my living as a freak'n professional rider." It ain't work like that.

Significant individuals typically play a crucial role in the composition of the lifestyle sport athletes' career, in a broader sense affecting their personal quest for their "element". The members of our focus groups agreed that their uptake of freeskiing and freestyle snowboarding was typically through related activities (skateboarding, gymnastics). Inspiration is typically attributed to people who recognize or sense the person's "element". The interviewed athletes reported significant individuals playing an important role in their initiation to freestyle and mentioned the supportive community as positively affecting their ongoing involvement in the sport. Anna (23), freestyle snowboarder from focus group 1 stated:

It was in fact thanks to my older brother who was working in the mountains, so I got to ski for cheap. $\mathrm{He}$ and his buddies went like ' $\mathrm{C}$ 'mon no girls snowboard you should try it out, being a gymnast there's no way you couldn't do the tricks' and so on. They took me to the park and said that when I've tried once I wouldn't want to go back to the slopes.

From the perspective of lifespan psychology, the "personal struggle for identity" begins in adolescence (Řičan, 2004, p. 216). Erikson (1980) points out that although the formation of identity is a lifelong process, it is during this particular period that identity is characterized by a significant tendency towards free, independent acting and attempting to live according to personal beliefs. Roberts (2011) on the other hand suggests we need to be cautious about claims that leisure activities such as lifestyle sports can act as base identities for individuals, citing inequalities in access to the opportunities to build a preferred leisure identity. Movement along the life course is related to a need to pursue activity and is accompanied by formation of life perspective. Ríčan (2004) considers the sense of perspective a crucial part of identity formation. The way individual sport identity develops may affect the athlete's perception of significant life change events. Adams (2003, p. 221) draws upon Giddens's (1991) theorizations of identity believing that "reflexive selfawareness provides the individual with the opportunity to construct self-identity without the shackles of tradition and culture...”. Although our participants express the importance of what Cyril (snowboard rider, 25, focus group 1) worded as "directing my own life", they generally present less radical way of reflecting on their future. Independent of gender, there is a significant number of statements in the data referring to the participants" vision of "normal" or "ordinary" course of life after they retire from professional sport career. This seems to support Zhao and Biesta's (2008) suggestion that the constitution of identity should not be seen merely as the reflective project of the self under latemodern conditions. In these authors' opinion, viewing the self strictly as adaptive and flexible may result in picturing life as "something that can be mastered or colonized". Although "walking their own path" (Pavel, 30 , freeskier, focus group 3) concerning how, where 
and with whom they ride, in the long term perspective, our interviewees seem to view life as something we have to come to terms with.

I doubt I'll ever stop riding because it's just become too much of a part of myself, but I don't see why I wouldn't have kids, maybe get married and follow that sort of life cycle like most people do. (Alena, 28 , professional freeskier, focus group 2)

At the same time the athlete refers to the sport activity having become an integral part of her recent construct of life.

\section{Limitations of the study}

We tried to address the issue of trustworthiness throughout the process of data collection, analysis and interpretation, ambition to generalize the results for the entire population of freeskiers and freestyle snowboarders could be misleading. Also, without the benefits of replicating established procedures and implementing validated sets of parameters, the judgment of significance and importance in studies employing qualitative research design always requires certain amount of intuition and experience, referred to as "data sensitivity" (Corbin \& Strauss, 1999). We thus admit that with the insights available in the later stages of the study, for example, possibly more productive questions could have been forged at the beginning.

\section{Conclusion}

Data indicate that instead of treating events within individual life stages as static and isolated, it is useful to recognize the existence of many overlaps in human lifespan. The study documents transformation of interpretation of critical life events along the life course. Among other involved factors the evolution can be attributed to every individual's change along the life journey as well as to the transformation of the given sport activity in the course of time. This contrasts with the mechanical images of a sport career commonly applied in institutionalized sport. A dynamic view on the human life-course becomes particularly useful when discussing the sustainability of a sport career in its increasingly non-linear layout with deep integration of the sport activity into the life of the interviewees. The inseparability of the pursued lifestyle sport activity from "who the athletes are" is repeatedly mentioned as key to their long term participation in it. These findings extend understanding of individualization in sport. The present study enhances existing knowledge in the field of lifestyle sport activities through the implementation of the lifespan approach. It also brings to the fore the importance of the cultural and social contexts within which the analyzed sport career histories take place. The further discussion should include sports recently tagged by lifestyle sport literature as mainstream in order to reflect the fact that simplistic distinction between mainstream and avant-garde forms of sport is recently being challenged.

\section{Conflict of interest}

There were no conflicts of interest.

\section{References}

Adams, M. (2003). The reflexive self and culture: A critique. British Journal of Sociology, 54, 221-238.

Alfermann, D., \& Stambulova, N. (2007). Career transitions and career termination. In G. Tenenbaum \& R. Eklund (Eds.), Handbook of Sport psychology (3rd ed., pp. 712733) New York, NY: John Wiley \& Sons.

Assink, M., \& Schroots, J. J. F. (2010). The dynamics of autobiographical memory: Using the LIM/Life-Line Interview Method. Göttingen, Germany: Hogrefe.

Atkinson, M., \& Young, K. (Eds.). (2008). Tribal play: Subcultural journeys through sport. Bingley, United Kingdom: Emerald Group Publishing.

Breivik, G. (2010). Trends in adventure sports in a postmodern society. Sport in Society, 13, 260-273.

Bryant, A., \& Charmaz, K. (2007). Grounded theory. London, United Kingdom: SAGE Publications Ltd.

Brymer, E. G., \& Oades, L. D. (2009). Extreme sports a positive transformation in courage and humility. Journal of Humanistic Psychology, 49, 114-126.

Celsi, R. L., Rose, R. L., \& Leigh, T. W. (1993). An exploration of high-risk leisure consumption through skydiving. The Journal of Consumer Research, 20, 1-23.

Charmaz, K. (2003). Grounded theory: Objectivist and constructivist methods. In N. K. Denzin \& Y. S. Lincoln (Eds.), Strategies of qualitative inquiry (2nd ed., pp. 249291). Thousand Oaks, CA: SAGE Publications, Inc.

Corbin, J., \& Strauss, A. (1999). Basics of qualitative research (3rd ed.). Thousand Oaks, CA: SAGE Publications, Inc.

Csikszentmihalyi, M. (2009). Flow. New York, NY: HarperCollins.

Deci, E. L., \& Ryan, R. M. (2008). Self-determination theory: A macrotheory of human motivation, development and health. Canadian Psychology, 49, 182-185.

Denzin, N. K. (1989). Interpretive biography. Thousand Oaks, CA: SAGE Publishing, Inc.

Denzin, N. K. (2014). Interpretive autoethnography. Thousand Oaks, CA: SAGE Publications, Inc.

Donnelly, M. (2006). Studying extreme sports. Beyond the core participants. Journal of Sport \& Social Issues, 30, 219-224.

Edwards, A., \& Skinner, J. (2009). Qualitative research in sport management. New York, NY: Routledge. 
Erikson, E. H. (1980). Identity and life cycle. New York, NY: W. Norton \& Company.

Giddens, A. (1991). Modernity and self-identity: Self and society in the late modern age. Stanford, CA: Stanford University Press.

Hodaň, B. (2009). K problému filozofické kinantropologie [To the problem of the philosophical kinanthropology]. Olomouc, Czech Republic: Palacký University Olomouc.

Hoffmannová, J. (2011). Proměnné v životní dráze sportovců u vybraných rizikových sportů (Biodromální pohled) [Variables in the life career of participants engaged in selected risk activities (Life span perspective)] (Unpublished doctoral dissertation). Palacký University Olomouc, Faculty of Physical Culture, Olomouc, Czech Republic.

Hrouda, T. (2004). Fenomén sportu v životní dráze člověka $s$ tělesným postižením [The phenomenon of sport in the career of a person with disabilities] (Unpublished doctoral dissertation). Palacký University Olomouc, Faculty of Physical Culture, Olomouc, Czech Republic.

Johnson, T. G., Bolter, N. D., \& Stoll, S. K. (2014). The play community: A student-centered model for physical education. Journal of Physical Education, Recreation \& Dance, 85, 20-27.

Le Breton, D. (2000). Playing symbolically with death in extreme sports. Body \& Society, 6, 1-11.

Lehnert, M., Hoffmannová, J., Neuls, F., Botek, M., \& Šebek, L. (2012). Individualization in sports training. In M. Lehnert et al. (Eds.), Anaerobic performance. Assessment and training (pp. 135-146). Olomouc, Czech Republic: Palacký University Olomouc.

Leonard, R., \& Burns, A. (2006). Turning points in the lives of midlife and older women: Five year follow up. Australian Psychologist, 41, 28-36.

Loland, S. (2007). Outline of a phenomenology of snowboarding. In M. J. McNamee (Ed.), Philosophy, risk and adventure sports (pp. 106-117). New York, NY: Routledge.

Maxwell, J. A. (2005). Qualitative research design: An interactive approach (2nd ed.). Thousand Oaks, CA: SAGE Publication, Inc.

Miovský, M. (2006). Kvalitativní prístup a metody v psychologickém výzkumu [Qualitative approach and methods in psychological research]. Prague, Czech Republic: Grada.

Morgan, D. L. (1997). The focus groups as qualitative research (2nd ed.). Thousand Oaks, CA: SAGE Publication, Inc.

Řičan, P. (2004). Cesta životem. Vývojová psychologie [The life journey. Developmental psychology]. Prague, Czech Republic: Portál.

Rinehart, R. E. (2008). ESPN'S X Games: Contest of opposition, resistance, co-option and negotiation. In M. Atkinson \& K. Young (Eds.), Tribal play: Subcultural journeys through sport (pp. 83-113). Bingley, United Kingdom: Emerald Group Publishing Limited.

Rinehart, R. E., \& Sydnor, S. (Eds.). (2003). To the extreme: Alternative sports, inside and out. Albany, NY: SUNY Press.

Roberts, K. (2011). Leisure: The importance of being inconsequential. Leisure Studies, 30, 5-20.

Robinson, K., \& Aronica, L. (2013). Finding your element: How to discover your talents and passions and transform your life. London, United Kingdom: Penguin.
Ryan, R., \& Deci, E. L. (2000). Self-determination theory and the facilitation of intrinsic motivation, social development, and well-being. American Psychologist, 55, 68-78.

Šebek, L. (2011). Specifické aspekty učení, motivace a adherence ke sportovní aktivitě u subkultury bikerů [Specific aspects of learning, motivation and adherence to sports activity in biking subculture] (Unpublished doctoral dissertation). Palacký University Olomouc, Faculty of Physical Culture, Olomouc, Czech Republic.

Šebek, L., \& Hoffmannová, J. (2010). Metoda focus group a možnosti jejího využití v kinantropologickém výzkumu [Focus group method and its application in kinanthropology research]. Tělesná kultura, 33(2), 30-49.

Silva, J. M., Metzler, J. N., \& Lerner, B. (2007). Training professionals in the practice of sport psychology. Morgantown, WV: Fitness Information Technology.

Stambulova, N. B., Alfermann, D., Statler, T., \& Côté, J. (2009). ISSP position stand: Career development and transitions of athletes. International Journal of Sport and Exercise Psychology, 7, 395-412.

Stebbins, R. A. (2004). Career and life course: Leisure as process. Retrieved from http://www.seriousleisure.net/ uploads/8/3/3/8/8338986/reflections6.pdf

Stebbins, R. A. (2005). Challenging mountain nature: Risk, motive, and lifestyle in three hobbyist sports. Calgary, Canada: Detselig.

Strauss, A., \& Corbin, J. (1990). Basics of qualitative research. Grounded theory procedures and techniques. Newbury Park, CA: SAGE Publishing.

Stuart, B., \& Smith, A. C. T. (2014). The significance of critical incidents in explaining gym use amongst adult populations. Qualitative Research in Sport, Exercise and Health, 6, 45-61.

Thorpe, H. (2009). Understanding "alternative" sport experiences: A contextual approach for sport psychology. International Journal of Sport and Exercise Psychology, 7, 359-372.

Thorpe, H. (2011). Snowboarding bodies in theory and practice. New York, NY: Palgrave Macmillan.

Thorpe, H. (2012). "Sex, drugs and snowboarding”: (Il)legitimate definitions of taste and lifestyle in a physical youth culture. Leisure Studies, 31, 33-51.

Valenta, T. (2009). Fenomén instruktorství v životní dráze člověka. Biografický výzkum metodou zakotvené teorie [The phenomenon of leadership in the human's life career. Biographic research based on the grounded theory method] (Unpublished doctoral dissertation). Palacký University Olomouc, Faculty of Physical Culture, Olomouc, Czech Republic.

Válková, H. (1990). Sociálně psychologické faktory a vývoj výkonnosti hráču košíkové [Social and psychological factors and the development of performance in basketball players]. Olomouc, Czech Republic: Palacký University Olomouc.

Wheaton, B. (2004). Understanding lifestyle sports. Consumption, identity and difference. New York, NY: Routledge.

Wheaton, B. (2013). The consumption and representation of lifestyle sports. Abingdon, United Kingdom: Routledge.

Wheaton, B., \& Beal, B. (2003). 'Keeping it real' subcultural media and the discourses of authenticity in alternative 
sport. International Review for the Sociology of Sport, 38, $155-176$

Wylleman, P., Alfermann, D., \& Lavallee, D. (2004). Career transitions in sport: European perspectives. Psychology of Sport and Exercise, 5, 7-20.

Yli-Piipari, S., Wang, J. C. K., Jaakkola, T., \& Liukkonen, J. (2012). Examining the growth trajectories of physical education students' motivation, enjoyment, and physical activity: A person-oriented approach. Journal of Applied Sport Psychology, 24, 401-417.
Young, K., \& Atkinson, M. (2008). Introduction: A subcultural history. In M. Atkinson \& K. Young (Eds.), Tribal play: Subcultural journeys through sport (pp. 1-49). Bingley, United Kingdom: Emerald Group Publishing Limited.

Zhao, K., \& Biesta, G. (2008). Lifelong learning, identity and the moral dimension: The "reflexive project of the self” revisited. In J. Crowther et al. (Eds.), Whither adult education in the learning paradigm? (pp. 558-565). Edinburgh, United Kingdom: University of Edinburgh/SCUTREA. 